\title{
PENERAPAN LABORATORIUM VIRTUAL UNTUK MENINGKATKAN PRESTASI BELAJAR MAHASISWA PADA MATAKULIAH FISIKA
}

\author{
Sigit Dwi Saputro ${ }^{1}$ \\ ${ }^{1}$ Dosen di Prodi Pendidikan Informatika \\ Fakultas Ilmu Pendidikan \\ Universitas Trunojoyo Madura \\ Bangkalan, 60231, Negara \\ E-mail: sigit_utm@yahoomail.com
}

\begin{abstract}
Abstrak
Penelitian tindakan kelas ini bertujuan untuk mengetahui pembelajaran fisika dengan media Virtual untuk meningkatkan hasil belajar pengukuran mahasiswa pada Program Studi S-1 Pendidikan Informatika Universitas Trunojoyo Madura (UTM). Telah ditemukan beberapa hasil penelitian terkini yang menyebutkan bahwa pembelajaran dengan media labolatorium Virtual berpengaruh terhadap hasil belajar. Pembelajaran yang berorientasi pada labolatorium dapat membantu peserta didik untuk membangun kebermaknaan dan mengotimalkan keterampilan proses pada saat pembelajaran yang dilakukan. Kegiatan penelitian dilakukan pada mahasiswa Program Studi Pendidikan Informatika kelas C . Penelitian ini akan dilakukan dalam beberapa prosedur penelitian meliputi perencanaan, pelaksanaan tindakan, observasi, dan refleksi. Instrumen yang digunakan antara lain: (1) Rencana perkuliahan dalam bentuk SAP yang menekankan pada strategi pembelajaran inkuiri, (2) Lembar observasi pelaksanaan perkuliahan, dan (3) Tes hasil belajar mahasiswa. Hasil penelitian ini yaitu penerapan laboratorium Virtual dapat meningkatkan hasil belajar belajar mahasiswa, khususnya pada materi pengukuran. Hal ini terlihat dari nilai mahasiswa sikuls 1 nilai rata-rata mahasiswa 70,05 dengan ketuntasan kalaiskal mahasiwa 69\%. Pada saat siklus 2 nilai rata-rata mahasiswa 90,67\% dengan ketuntasan kalaiskal mahasiwa 97\%.
\end{abstract}

Kata Kunci: Laboratorium Virtual, Prestasi Belajar

\begin{abstract}
This classroom action research aims to determine the physics learning with virtual media to improve student learning outcomes measurements on undergraduate program of Informatics Education of University Trunojoyo Madura (UTM). It has been found that some of the latest research says that learning with virtual labs media influence on learning outcomes. Laboratory based learning can help learners to build meaningfulness and optimize skills during the learning process is carried out. The research activities conducted on Informatics Education students in class $C$. This study will be conducted in several research procedures such as planning, action, observation, and reflection. Instruments used such as: (1) Plan of lectures in the form of SAP emphasis on inquiry learning strategy, (2) the implementation of the observation sheet lecture, and (3) Test results of student learning. The results of this research is the application of virtual labs to improve learning outcomes of student learning, particularly in the matter of measurement. This can be seen from the students' scores first cycle average value of students 70.05 with students classical completeness 69\%. At the second cycle, average value of students is $90.67 \%$ with students classical completeness $97 \%$.
\end{abstract}

Keywords: virtual media, learning outcomes. 


\section{Pendahuluan}

Undang-Undang RI Nomor 20 Tahun 2003 tentang sistem pendidikan Nasional mendefinisikan "pembelajaran adalah suatu proses interaksi antara peserta didik dengan pendidik dan sumber belajar pada suatu lingkungan belajar". Dalam hal ini pembelajaran dipandang sebagai suatu proses dimana lingkungan seseorang secara sengaja dikelola untuk memungkinkan ia turut serta dalam tingkah laku tertentu dalam kondisikondisi khusus atau menghasilkan respons terhadap situasi tertentu. Dari definisi tersebut dapat disimpulkan bahwa pembelajaran di sekolah pada dasarnya adalah proses penciptaan atau pengkondisian sebuah lingkungan sekolah atau kelas yang memungkinkan peserta didik belajar.

Pengondisian yang ada di kelas, warga kelas memiliki kendali terhadap penciptaan tersebut dan guru menjadi pendesainnya. Dalam pengendalian kondisi tersebut guru menggunakan pendekatan atau model pembelajaran tertentu. Rostiyah (2001) mendefinisikan "pendekatan pembelajaran sebagai jalan yang digunakan oleh guru atau pembelajar untuk menciptakan suasana yang memungkinkan peserta didik belajar". Berdasarkan pendapat-pendapat tersebut dapat disimpulkan bahwa dalam ruang lingkup kelas, model pembelajaran dapat diartikan sebagai suatu jalan atau cara yang ditempuh oleh guru dan peserta didik untuk menciptakan atau mengondisikan suasana kelas yang memungkinkan adanya proses atau interaksi belajar mengajar. Dalam hal ini seorang guru memiliki peran yang sangat penting dalam proses pembelajaran di kelas, karena tugas guru adalah mendesain termasuk memilih pendekatan atau model pembelajaran yang dapat digunakan untuk mengendalikan pembelajaran dalam kelas sehingga tercipta suasana kelas dan suasana pembelajaran yang kondusif dan terkondisi untuk belajar.
Kaitannya dengan makna belajar dan hasilnya, Winkel (1996) menyatakan bahwa belajar merupakan suatu aktivitas mental yang berlangsung dalam interaksi aktif dengan lingkungan yang menghasilkan perubahan dalam pengetahuan, pemahaman, keterampilan serta sikap dan perubahan ini bersifat relatif konstan dan berbekas. Hasil belajar peserta didik ditentukan oleh sejauh mana peserta didik terlibat secara mental dalam kegiatan belajar. Keterlibatan ini diartikan sampai sejauh mana kedekatan peserta didik dengan objek belajar. Masing-masing cara dalam penyajian konsep akan menentukan pemahaman peserta didik sehingga jika kedekatan materi belajar terjadi pada peserta didik maka peserta didik akan merasakan adanya keterlibatan mental. Model pembelajaran yang digunakan guru menentukan sampai sejauh mana keterlibatan peserta didik secara mental dalam proses belajar. Pendekatan dan proses pembelajaran menentukan seberapa banyak muatan atau isi dari suatu pengalaman yang diperoleh peserta didik terkait dengan pengetahuan, sikap, dan keterampilan yang diharapkan.

Ilmu pengetahuan alam adalah ilmu yang mempelajari berbagai fenomena dan hukum alam. Adapun ilmu pengetahuan alam itu mencakup: sub bidang studi kimia, biologi, geologi, astronomi dan salah satunya adalah fisika. Menurut Millar dalam Ahmad (2011), menyatakan bahwa ilmu pengetahuan alam dapat dibagi menjadi tiga kategori, yaitu berdasarkan isi, metode, dan proses. Kategori isi dalam ilmu pengetahuan terbagi menjadi beberapa aspek yaitu: fakta, gagasan, konsep, teori, dan hukum, sedangkan metode dan proses merupakan suatu hal pokok yang digunakan untuk membangun dan mengembangkan sikap, dan nilai berdasarkan pengetahuan ilmiah melalui percobaan ilmiah. Ahmad (2011) menyatakan bahwa:

Fisika adalah ilmu yang mengkaji interaksi antara energi dan materi yang menjadi dasar dari ilmu pengetahuan alam. Dalam pembelajaran fisika di sekolah menengah atas, 
siswa diharapkan tidak hanya menguasai konsep-konsep fisika secara teori tetapi juga mampu menggunakan metode ilmiah untuk membuktikan konsep-konsep fisika yang didapat dari teori tersebut.

Fisika merupakan salah satu cabang ilmu pengetahuan alam yang menggambarkan gejala-gejala alam yang ada secara kuantitatif dengan sifat obyektif sehingga perbedaan pendapat dan kesalah pahaman menafsirkan sesuatu hal dapat dihindari. Dalam hal ini pembelajaran fisika diharapkan tidak hanya sekedar menguasai konsep-konsep fisika secara teoritis tetapi juga mampu menggunakan metode ilmiah untuk membuktikan konsepkonsep fisika yang didapat dari teori tersebut. Berdasarkan hal tersebut, secara tidak langsung siswa dapat meningkatkan aspek keterampilan proses dasar yang dimiliki berdasarkan kerja ilmia yang dilakukan (Ahmad 2011).

Menurut Wospakrik dalam Mundilarto (2010: 3) menyatakan bahwa fisika merupakan cabang ilmu alam yang pada dasarnya bertujuan untuk memperlajari dan memberi pemahaman baik secara kualitatif maupun kuantitatif tentang berbagai gejala atau proses alam dan sifat zat serta penerapannya. Fisika merupakan suatu cabang ilmu pengetahuan sains yang mempelajari sesuatu pengetahuan alam yang bersifat deterministik dan konkret yang meliputi teori, hukum, kaidah, dan asasasas fisika serta dapat dibuktikan secara ilmiah berdasakan hasil penelitian (Mundilarto, 2010). Sejalan dengan hal tersebut, bahwa fisika sebagai ilmu dasar memiliki karakteristik yang mencakup bangun ilmu yang terdiri atas fakta, konsep, prinsip, hukum, postulat, dan teori serta metodologi penelitian (Mundilarto, 2010: 4). Dalam hal ini fisika merupakan suatu ilmu yang secara tidak langsung dapat memberikan dampak yang baik terhadap perkembangan suatu bentuk keterampilan-keterampilan karena pada dasarnya dalam fisika menuntut lebih banyak kerja ilmiah.

Berdasarkan pendapat ahli dapat disimpulkan bahwa fisika merupakan salah satu cabang ilmu pengetahuan alam (IPA) yang mempelajari gejala alam atau fenomena alam serta semua interaksi yang menyertainya. Tujuan dari mempelajari gelaja tersebut untuk memperoleh produk fisika yang bersifat khas, dan dapat menjelaskan gejala alam tersebut dengan produk pembelajaran fisika yang terdiri dari konsep, hukum dan teori. Selain itu, fisika juga disebut sebagai produk, dan proses, yang meliputi fakta, konsep, prinsip, dan teorri, sedangkan sebagai proses meliputi keterampilan-keterampilan, dan sikap ilmiah.

Sejalan dengan hal tersebut, berdasarkan pendapat para ahli juga disimpulkan bahwa pembelajaran fisika merupakan suatu kegiatan belajar mengajar atau kegiatan guru yang dirancang untuk menciptakan interaksi antara siswa dengan guru dan sumber belajar pada suatu lingkungan belajar yang didalamnya mempelajari alam, dan kejadian-kejadiannya untuk mencapai tujuan yang diharapkan yang berupa produk, dan proses. Pembelajaran fisika akan lebih cepat dipahami jika diajarkan sesuai hakikat fisika, yaitu meliputi produk dan proses, serta diharapkan bahwa siswa dapat menemukan fakta, membangun konsep sendiri berdasarkan asimilasi pengalaman yang dilakukan, teori, dan sikap ilmiah yang dapat berpengaruh positif terhadap kualitas maupun pembelajaran, sehingga mampu menghasilkan penguasaan fisika dengan baik.

Laboratorium virtual berbeda dengan laboratorium real, pada laboratorium virtual alat dan bahan yang digunakan untuk melakukan kegiatan praktikum adalah seperangkat komputer lengkap dengan software yang dirancang khusus untuk kegiatan eksperimen. Software ini berisi animasianimasi alat bahan dan desain untuk kegiatan eksperimen, dengan menggunakan media komputer sebagai media pembelajaran, harus direncanakan secara sistematik agar pembelajaran dan penggunaan komputer dapat berjalan dengan efektif. Pembelajaran dengan menggunakan komputer perlu direncanakan dengan baik agar: 
Menumbuhkan minat peserta didik; (2) Menyampaikan materi baru; (3) Melibatkan peserta didik secara aktif; (4) Mengevaluasi tingkat pemahaman siswa; (5) Menetapkan tindak lanjut.

Berkenaan dengan masalah biaya, bagi sekolah penggunaan laboratorium virtual tidaklah mahal, hal itu akan sangat terasa apabila alat dan bahan yang dipergunakan untuk melakukan eksperimen di laboratorium real mahal (tidak terjangkau). Untuk dapat mengaplikasikanya hanya dibutuhkan seperangkat komputer dan softwarenya. Sedangkan menurut Bekir Bayrak (2007) mengatakan bahwa "tidak ada perbedaan hasil belajar yang nyata antara arahan laboratorium dengan arahan komputer", artinya belajar dengan menggunakan komputer pada laboratorium virtual sama efektifnya dengan belajar menggunakan laboratorium real.

Berdasarkan rata-rata nilai kelas pendidikan Informatika $1 \mathrm{C}$ masih rendah yaitu 63,67, jika di kategirikan angka masih $\mathrm{C}$. Hal ini menunjukkan perlu adany tindkkan untuk mempengaruhi dari hasil belajar mahasiswa. Adapun tindakan untuk memperbaiki dari hasil belajar mahasiswa perlu mengetahui karakteristik matakuliah dan mahasiswa.

Berdasarkan hal tersebut, maka peneliti ingin menerapkan labolatorium virtual dalam pembelajaran pengukuran untuk meningkatkan prestasi belajar mahasiswa. Tujuan yang diharapkan adalah proses pembelajaran yang demikian dapat memberikan pengalaman langsung kepada mahasiswa, dan pengalaman langsung yang memungkinkan materi pelajaran akan semakin konkrit, yang berarti proses pembelajaran akan lebih bermakna..

\section{Metode Penelitian}

Metode penelitian meliputi subjek penelitian, rancangan penelitian, prosedur penelitian, teknik pengumpulan data, dan teknik analisis data.
Subjek penelitian ini adalah Subjek penelitian adalah mahasiswa kelas C Prodi Pendidikan Informatika UTM dengan jumlah mahasiswa 46 orang. Penelitian tindakan ini dilaksanakan di ruang kuliah Prodi Pendidikan Informatika UTM yakni di Gedung RKB D 304 UTM.

Prosedur penelitian yang digunakan dalam penelitian ini adalah prosedur penelitian tindakan (action research). Penelitian ini dilakukan secara tim oleh dua orang dosen, dimana satu orang sebagai pelaku tindakan dan satu lainnya menjadi observer.

Adapun tahap-tahap penelitian tersebut pertama, tahap Perencanaan TindakanDalam hal ini tim peneliti secara kolaboratif menyusun rencana tindakan, untuk upaya meningkatkan daya serap mahasiswa pada mata kuliah Strategi Pembelajaran. Adapan kegiatan dalam tahap ini meliputi: (a) menyusun Satuan Acara Perkuliahan (SAP), (b) memetakkan materi ajar dan membaginya menjadi unit-unit kecil, (c) menyusun lembar observasi pelaksanaan perkuliahan untuk mengetahui sejauh mana pelaksanaan strategi pembelajaran inkuiri dapat dilaksanakan, (d) merencanakan pelaksanaan tindakan dengan menggunakan pedoman observasi yang telah disiapkan, (e) menentukan pelaksana tindakan dan observer, dan (f) menyusun tes hasil belajar mahasiswa untuk mengetahui tingkat daya serap mahasiswa terhadap materi kuliah.

Kedua, tahap pelaksanaan pindakan

dosen (peneliti) menerapkan strategi pembelajaran inkuiri dalam proses perkuliahan sesuai dengan SAP yang telah disusun. Pelaksanaan tindakan ini diupayakan untuk menerapkan strategi pembelajaran inkuiri dengan optimal dan meningkatkan daya serap mahasiswa menjadi lebih meningkat dari kondisi awal.

Kertiga, pengamatan/observasi untuk mengenali dan mengamati gejala-gejala yang muncul baik yang mendukung maupun yang menjadi kendala pengalaman belajar dalam penelitian untuk meningkatkan daya serap 
mahasiswa serta gejala perubahan perilaku yang tampak sebagai hasil dari tindakan yang diberikan. Dalam hal ini observasi ditekankan pada dua hal, yakni pada pelaku tindakan (dosen yang mengajar) dan kegiatan belajar mahasiswa.

Empat, tahap refleksi/evaluasi yaitu melakukan refleksi terhadap hasil yang diperoleh pada saat melakukan tindakan. Dalam hal ini seluruh data yang sudah terekam selama observasi didiskusikan bersama yakni oleh tim peneliti sebagai dasar perbaikan tindakan berikutnya. Hasil yang diperoleh pada tindakan pertama (siklus I) dievaluasi dan dijadikan bahan pertimbangan untuk tindakan berikutnya (siklus II). Selain itu hasil refleksi dijadikan dasar bagi pelaku tindakan (dosen) untuk merefleksi diri sendiri sehingga dapat mengetahui letak kelemahan dari hasil tindakan untuk dilakukan upaya perbaikan pada tindakan berikutnya.

Pengambilan data dalam penelitian tindakan ini meliputi data 1). rencana perkuliahan dalam bentuk SAP yang menekankan strategi pembelajaran inkuiri. 2). data pelaksanaan yaitu dikumpulkan melalui pengamatan (observasi) yang akan dilakukan oleh observer, 3).data tingkat daya serap mahasiswa terhadap materi kuliah Strategi Pembelajaran, yakni tingkat ketercapaian kompetensi mata kuliah. Data ini diperoleh melalui tes yang dilakukan pada akhir setiap siklus tindakan. Instrumen penelitian berupa tes hasil belajar siswa berbentuk tes uraian

Analisis data tentang rencana perkuliahan dan data pelaksanaan strategi pembelajaran inkuiriberupa hasil observasi dan refleksi dilakukan dengan deskripsi kualitatif serta divalidasi secara kolaboratif untuk memperoleh informasi yang akurat dan dikritisi dalam tahap refleksi. Sedangkan data tingkat daya serap mahasiswa terhadap materi kuliah dianalisis dengan deskripsi komparatif dengan perbandingan tingkat daya serap kondisi awal dan tingkat daya serap mahasiswa pada setiap siklus kegiatan serta divalidasi dengan melakukan validasi butir soal dengan cara menyusun kisi-kisi soal sesuai dengan kompetensi mata kuliah.

Selain itu, pengecekan keabsahan keseluruhan data penelitian dilakukan melalui: (1) penggunaan indikator kinerja secara optimal, (2) ketekunan dalam pengamatan, (3) triangulasi data, serta (4) pengecekan/review teman sejawat.

\section{Hasil Penelitian dan Pembahasan}

Hasil penelitian penerapan laboratorium virtual pembelajaran yang telah diimplementasikan di Prodi Pendidikan Informatika Universitas Trunojoyo Madura berupa keterlaksaanaan deskriopsi data siklus 1, siklus 2. Pembahasan sikus 1 dan siklus 2.

Tabel 4.2 Ringkasan Hasil Siklus 1 dan Siklus 2

\begin{tabular}{lcll}
\hline \multicolumn{2}{c}{ Siklus 1} & \multicolumn{2}{c}{ Siklus 2 } \\
\hline Rata-rata & 70,05 & Rata-rata & 90,67 \\
Nilai & & Nilai & \\
Lulus & 29 & Lulus & 41 \\
Tidak & 13 & Tidak & 1 \\
Lulus & & Lulus & \\
\hline
\end{tabular}

Berdasarkan Tabel 5.1 dan $\quad 5.2$ menunjukkan bahwa jumlah mahasiswa dalam satu kelas yaitu 42, adapun Siklus 1 nilai ratarata 70,05 mahasiswa yang nilainya melebihi rata-rata KKM (70) sebanyak 29 dan kurang dari KKM berjumlah 13. Sedangkan pada Siklus 2 nilai rata-rata 90,67 mahasiswa yang nilainya melebihi rata-rata KKM (70) sebanyak 41 dan kurang dari KKM berjumlah 1 .

Ketuntasan klasikal mahasiswa pada Siklus 1 yaitu $\frac{29}{42}=0,69=69 \%$. Dengan demikian mahasiswa dalam Siklus 1 tidak dapat memenuhi standart KKM yang ditentukan, yaitu 70 dengan ketuntasan klasikal $69 \%<75 \%$. Adapun ketuntasan klasikal Siklus 1 dapat terlihat pada Gambar 5.1. 


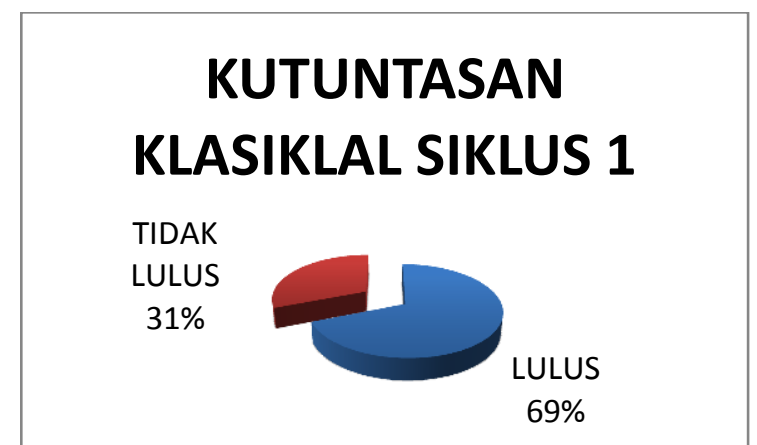

Gambar 1. Ketuntasan klasikal siklus 1

Ketuntasan klasikal mahasiswa pada Siklus 2 yaitu $\frac{41}{42}=0,69=97 \%$. Dengan demikian mahasiswa dalam Siklus 2 dapat memenuhi standart KKM yang ditentukan, yaitu 70 dengan ketuntasan klasikal 97\% > $75 \%$. Adapun ketuntasan klasikal Siklus 1 dapat terlihat pada Gambar 5.1.

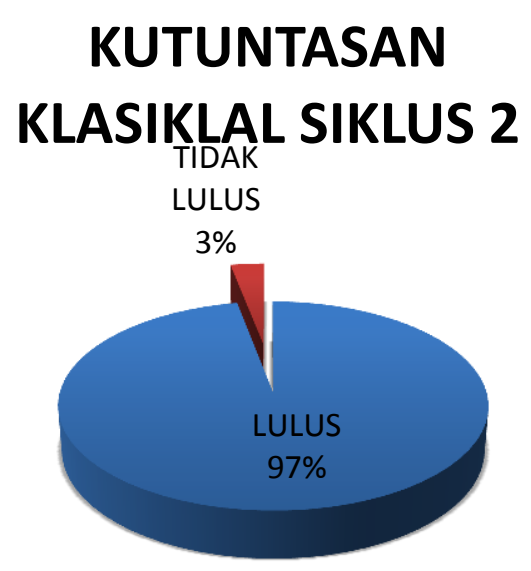

Gambar 2. Ketuntasan klasikal siklus 2

Pembahasan Siklus 1

Berdasarkan pemaparan prestasi mahasiswa rata-rata kelas pada saat Siklus 1 70,05 sedangkan ketuntasan klasikal hanya $69 \%$, dapat disimpulkan bahwa ketuntasan klasikal mahasiswa tidak memenuhi stándar KKM yang telah ditetapkan.

Pada siklus pertama masih ditemukan sejumlah 13 siswa dari 42 siswa atau $31 \%$ masih acuh tak acuh terhadap proses pembelajaran, kurang merespon penjelasan dosen.
Tabel 1. Lembar pengamatan aktivitas mahasiswa

\begin{tabular}{|c|l|c|c|}
\hline No & Jenis Respon & $\begin{array}{c}\text { Freku } \\
\text { ensi }\end{array}$ & $\begin{array}{c}\text { Persen } \\
\text { tase }\end{array}$ \\
\hline 1 & Bertanya & 2 & $5 \%$ \\
\hline 2 & $\begin{array}{l}\text { Mengerjakan } \\
\text { tugas }\end{array}$ & 38 & $90 \%$ \\
\hline 3 & $\begin{array}{l}\text { Menjawab } \\
\text { kuis }\end{array}$ & 6 & $14 \%$ \\
\hline 4 & $\begin{array}{l}\text { Berpartisipas } \\
\text { i aktif dalam } \\
\text { kelompok }\end{array}$ & 18 & $42 \%$ \\
\hline
\end{tabular}

Tabel di atas menunjukkan bahwa secara umum siswa kurang aktif dalam aktivitas bertanya, menjawab kuis maupun berkelompok. Sedangkan menurut Semiawan (1992) Pengembangan ketrampilan proses sains akan melatih siswa mampu menemukan dan mengembangkan sendiri fakta dan konsep serta menumbuhkan dan mengembangkan sikap dan nilai. Sehingga dari data hasil pengamatan menjadi dasar untuk perbaikan dalam pembelajaran labolatorium virtual pada siklus kedua.

Pembahasan Siklus 2

Berdasarkan pemaparan prestasi mahasiswa rata-rata kelas pada saat siklus kedua yaitu 90,67, sedangkan ketuntasan klasikal hingga 97\%, dapat disimpulkan bahwa ketuntasan klasikal mahasiswa memenuhi stándar KKM yang telah ditetapkan.

Hasil ini sesuai dengan Jaya (2013) yang menyatakan bahwa penggunaan laboratorium simulasi dapat memenuhi kriteria dan efisien dalam proses praktikum sehingga siswa sangat terbantu dan kemandirian siswa dalam melakukan kegiatan praktek dapat tercapai. Laboratorium simulasi dapat di kategirikan sebagai labolatorium virtual karena sama-sama menggunakan benda virtual saat melakukan kegiatan belajar mahasiswa. 
Begituhalnya penelitian Winarti (2009) saputro (2010) dan menyimpulkan bahwa labolatorium Virtual dapat mingkatkan kemampuan memori dan sikap ilmiah. Sehingga mahasiswa saat melakukan praktikum menggunakan labolatorim virtual kemampuan memori dan sikap ilmiah terasah sehingga berdampak terhadap prestasi

\section{Kesimpulan dan Saran}

Berdasarkan hasil penilitian dan pembahasannya yang telah diuraikan sebelumnya dapat disimpulkan sebagai berikut.

Penerapan laboratorium virtual dapat meningkatkan hasil belajar belajar mahasiswa, khususnya pada materi pengukuran. Hal ini terlihat dari nilai mahasiswa sikuls 1 nilai ratarata mahasiswa 70,05 dengan ketuntasan kalaiskal mahasiwa 69\%. Pada saat siklus 2 nilai rata-rata mahasiswa $90,67 \%$ dengan ketuntasan kalaiskal mahasiwa 97\%

Saran-saran yang perlu peneliti berdasarkan hasil penelitian ini sebagai berikut para pendidik dapat mempertimbangkan menggunakan menggunakan laboratorium virtual saat proses pembelajaran untuk meningkatkan hasil belajar ditengah keterbatasan dari alat peraga

Dalam melaksanakan pembelajaran agar selalu diupayakan mahasiswa yang aktif untuk melakukan belajar, sedangkan pendidik menjadi motivator dan fasilitator.

\section{Daftar Pustaka}

Ahmad, F. (2011). Pentingnya pembelajaran fisika melalui kegiatan laboratorium fisika berbasis inquiry. Orbith, 7, 86-93.

Bekir Bayrak. 2007. To Compare the Effect of Computer Based Learning and The Laboratory Based Learning on Student's Acheievement Regarding
Electric Circuits. Turkish Journal of Educational Technology. Vol 6.

Kemendiknas. Undang-Undang Standar Pendidikan Nasional No. 20 Tahun 2003. Jakarta: Kemdiknas

Mundilarto. (2010). Penilaian Hasil Belajar Fisika. Yogyakarta: UNY Press.

Roestiyah. 2001. Strategi Belajar Mengajar. Jakarta : Rineka Cipta

Saputro, Eko Bambang. 2010. Pembelajaran IPA Dengan Inkuiri Terbimbing Melalui Metode Eksperimen Menggunakan Lab Riil Dan Virtuil Ditinjau Dari Aktivitas Siswa Dan Sikap Ilmiah (Studi Kasus Pada Materi Pemantulan Dan Pembiasan Cahaya Kelas VIII Semester 2 SMP Negeri 4 Demak. Tesis: UNS

Winarti, Titin Catur. 2009. Pembelajaran fisika menggunakan pendekatan CTL dengan eksperimen laboratorium dan eksperimen Virtual dengan mempertimbangkan Kemampuan memori siswa pada materi pokok asam, basa dan garam siswa kelas VII SMP N 1 Semarang. Tesis: UNS

W.S. Winkel. 1996. Psikologi Pengajaran. Jakarta: Grasindo. 